\title{
NAPHTHOQuinones in Pygmy Sundews (DROSERA SECT. BRYASTRUM)
}

JAN SCHLAUER • Zwischenstr. 11 • D-60594 Frankfurt/Main• Germany • jan@carnivorousplants.org AndREAS FleISCHMANN • Botanische Staatssammlung München • Menzinger Strasse $67 \cdot$ D-80638 Munich•Germany・fleischmann@bio.lmu.de

Keywords: Drosera, phytochemistry, naphthoquinones, chemotaxonomy.

Abstract: A detailed study of 44 accessions representing 38 taxa (76\% of the diversity known at present) of pygmy sundews (Drosera sect. Bryastrum) reveals the first naphthoquinone patterns in this lineage, in which previous studies have not yielded reliable evidence for naphthoquinones. While most samples do not display detectable amounts of naphthoquinones as previously reported for the group, ramentaceone is detected in three mutually related taxa, and both ramentaceone and its regio-isomer plumbagin is present in all accessions investigated of D. pulchella.

\section{Introduction}

Pygmy sundews (Drosera sect. Bryastrum) are a well-defined lineage of ca. 50 species almost entirely confined to southwestern Western Australia (Fleischmann et al. 2018; Robinson et al. 2018). Only the more widespread D. pygmaea (reaching New Zealand) and the curiously disjunct D. meristocaulis (endemic to southernmost Venezuela) occur elsewhere. Almost all species (except the tropical $D$. meristocaulis) are known to form gemmae that are vegetative propagules from modified leaves (Goebel 1908; Rivadavia et al. 2013; Lowrie 2014: 44-58 \& 116-151).

While naphthoquinones like plumbagin (2-methyljuglone, P) and ramentaceone (7-methyljuglone, M) have been known for a long time as characteristic, chemotaxonomically informative metabolites in the genus Drosera, they have not been detected with any certainty in pygmy sundews yet. A single, dubious report (reference to unpublished data without any experimental details) of $\mathbf{P}$ in D. pygmaea (Krenn in Länger et al. 1995) stands in clear contrast to negative results from a previous, comprehensive screening (Culham and Gornall 1994).

More recently, the re-investigation of species formerly believed devoid of naphthoquinones has yielded some unexpected, positive results (P in D. menziesii, Schlauer et al. 2018, $\mathbf{M}$ in D. arcturi, Schlauer et al. 2019a, and in D. schizandra, Schlauer et al. 2019b). The removal of ripe gemmae does not damage the rosettes that produced them, so this material was investigated for the first time in the present study.

Among numerous confirmed and new negative results, a few species are reliably found to contain $\mathbf{M}$, and $D$. pulchella, previously considered devoid of naphthoquinones whatsoever, even contains both $\mathbf{M}$ and $\mathbf{P}$.

\section{Materials and methods}

All plants used in the present study were raised from gemmae and cultivated at Andreas Fleischmann's greenhouse in southern Germany (Figs. 1 \& 2). The geographic origin of all accessions was traced as far as possible (see Table 1). Ten to twenty fresh, ripe gemmae (ca. $10 \mathrm{mg}$ ) of each accession were harvested and investigated under the same conditions applying the same methods as 


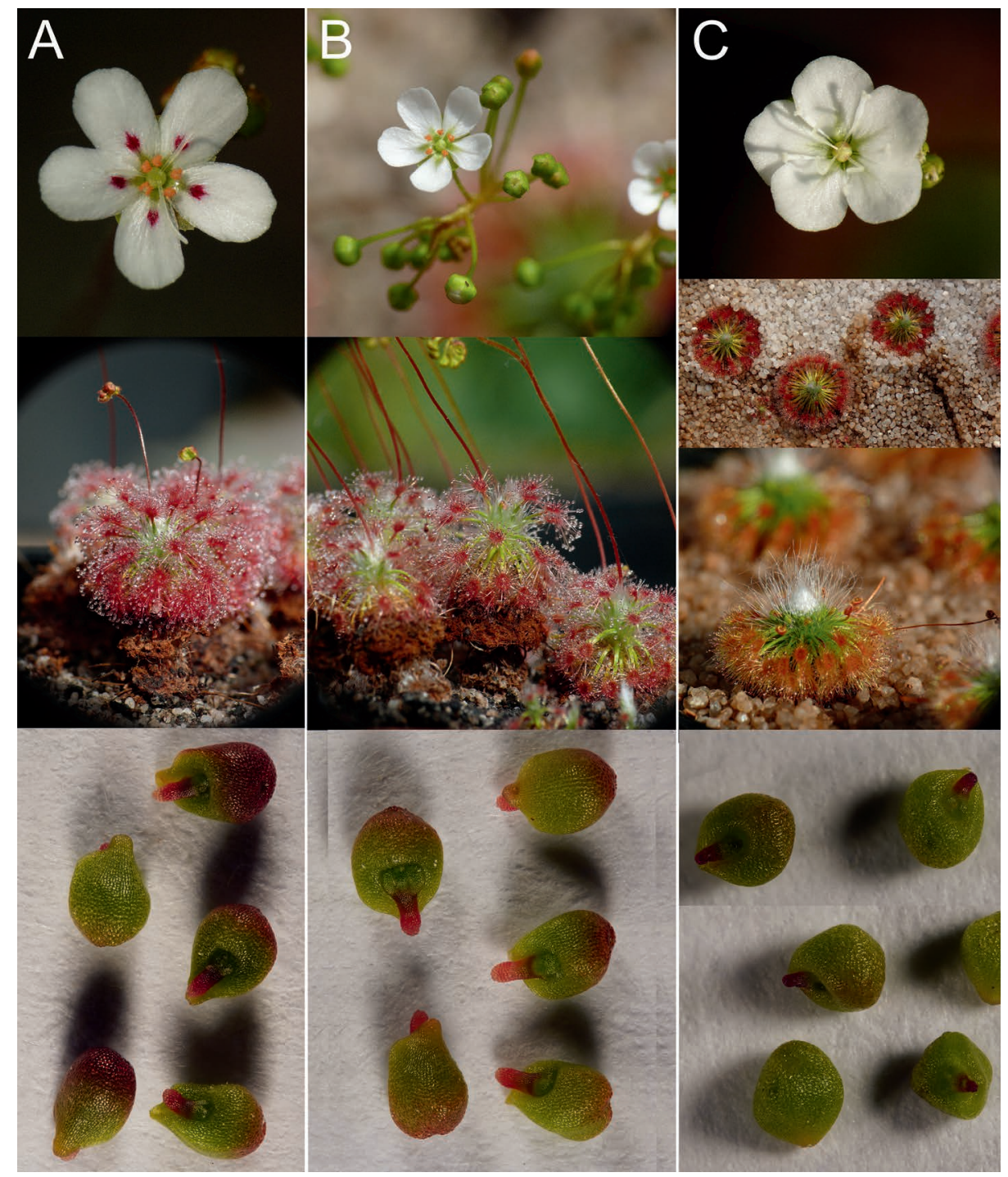

Figure 1: Flower, habit, and gemmae of the three M-positive members of Drosera sect. Bryastrum: A. D. minutiflora. B. D. pedicellaris. C. D. sargentii. Flower and habit images not at the same scale. Plants cultivated by A. Fleischmann, photo vouchers were made for the material used in this study.

reported previously for the investigation of leaves (Schlauer et al. 2017). Additionally, fresh leaves were investigated for some species or as control of the gemmae results.

\section{Results}

Naphthoquinones were detected in the investigated samples as summarized (together with previous results) in Table 1. 


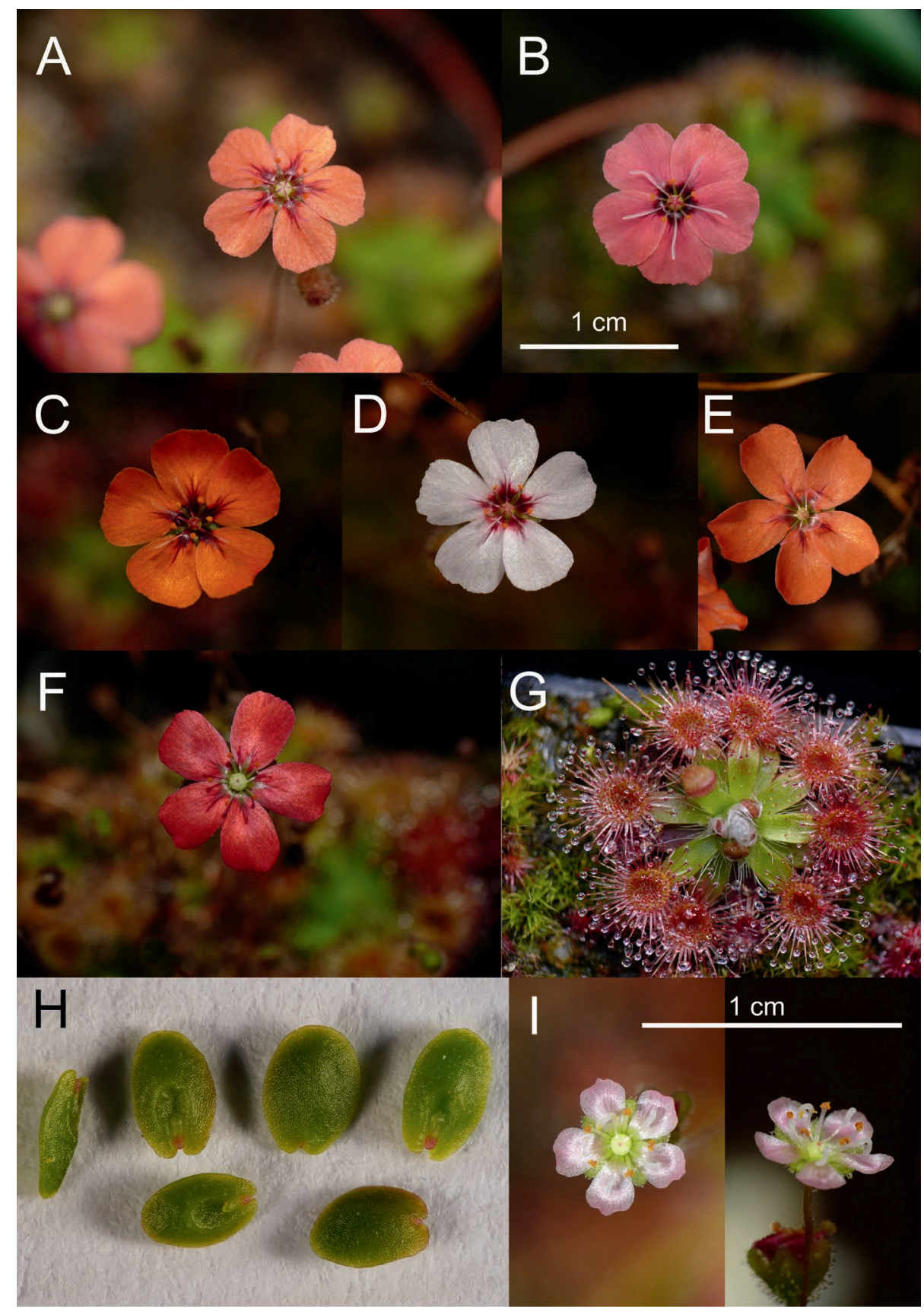

Figure 2: Drosera pulchella $(\mathrm{A}-\mathrm{H})$ and $D$. depauperata (I). Accessions of $D$. pulchella from Scott River, Western Australia (A, flower; H, gemmae), clone 52-A (B); Baker's Junction, Western Australia (C, flower; $G$, habit), white flower, red center (D), Mount Cooke, Western Australia (E), red flower (F). Images not at the same scale. Plants grown and photographed by A. Fleischmann. 


\begin{tabular}{|c|c|c|c|c|}
\hline Taxon a & Accessions & Provenance & Quinone(s) ${ }^{b}$ & References $^{c}$ \\
\hline D. androsacea & 1 & $\begin{array}{l}\text { Western Australia } \\
\text { (WA) }\end{array}$ & 0 & * \\
\hline D. (occidentalis subsp.) australis & 1 & WA & 0 & $*$ \\
\hline D. barbigera & 1 & & 0 & 1 \\
\hline D. bindoon & 1 & Bindoon, WA & 0 & $*$ \\
\hline D. callistos & 1 & Brookton, WA & 0 & $*$ \\
\hline D. citrina & 1 & Regans Ford, WA & 0 & $*$ \\
\hline D. closterostigma & 1 & (type form), WA & 0 & $*$ \\
\hline D. coomallo & 1 & Coomallo, WA & 0 & $*$ \\
\hline D. depauperata & 1 & $\begin{array}{l}\text { locus classicus, } \\
\text { WA }\end{array}$ & 0 & $*$ \\
\hline D. echinoblastus & 1 & WA & 0 & $*$ \\
\hline D. enneabba & 2 & $\begin{array}{l}\text { Moore River NP, } \\
\text { WA; (red from), } \\
\text { WA }\end{array}$ & 0 & $*$ \\
\hline D. gibsonii & 1 & WA & 0 & $*$ \\
\hline D. grievei & 1 & WA & 0 & $*$ \\
\hline D. helodes & 2 & $\begin{array}{l}\text { Bullsbrook, WA; } \\
\text { Great Northern } \\
\text { Highway, WA }\end{array}$ & 0 & $*$ \\
\hline D. hyperostigma & 1 & WA & 0 & $*$ \\
\hline D. lasiantha & 1 & $\begin{array}{l}\text { Porongorup NP, } \\
\text { WA }\end{array}$ & 0 & $*$ \\
\hline D. leucoblasta & 1 & & 0 & 1 \\
\hline D. (nitidula var.) leucostigma & 1 & WA & 0 & $*$ \\
\hline D. mannii & 1 & WA & 0 & $*$ \\
\hline D. meristocaulis & 1 & $\begin{array}{l}\text { Sierra de la } \\
\text { Neblina, Venezuela }\end{array}$ & 0 & 2 \\
\hline D. (occidentalis var.) microscapa & 1 & $\begin{array}{l}\text { locus classicus, } \\
\text { WA }\end{array}$ & 0 & $*$ \\
\hline D. miniata & 1 & (type form), WA & 0 & $*$ \\
\hline D. nitidula & 1 & & 0 & 1 \\
\hline D. (citrina var.) nivea & 1 & WA & 0 & $*$ \\
\hline D. occidentalis & 3 & & 0 & 1 \\
\hline D. (nitidula subsp.) omissa & 1 & & 0 & 1 \\
\hline D. (nitidula subsp.) omissa & 1 & (pink flower), WA & $\mathrm{M}(+\mathrm{P}$-trace $)$ & $*$ \\
\hline D. oreopodion & 1 & $\begin{array}{l}\text { locus classicus, } \\
\text { WA }\end{array}$ & 0 & $*$ \\
\hline D. micrantha & 1 & & 0 & 1 (as “D. paleacea”) \\
\hline
\end{tabular}




\begin{tabular}{|c|c|c|c|c|}
\hline Taxon ${ }^{a}$ & Accessions & Provenance & Quinone(s) ${ }^{b}$ & References $^{c}$ \\
\hline D. micrantha & 1 & WA & 0 & $*$ \\
\hline D. paleacea & 1 & WA & 0 & $*$ \\
\hline D. minutiflora (?) & 1 & & 0 & 1 (as "D. parvula") \\
\hline D. minutiflora & 1 & WA & M & $*$ \\
\hline D. (nitidula var.) patens & 1 & WA & 0 & * \\
\hline D. (parvula var.) pedicellaris & 1 & $\begin{array}{l}\text { locus classicus, } \\
\text { WA }\end{array}$ & M & $*$ \\
\hline D. platystigma & 1 & & 0 & 1 \\
\hline D. pulchella & 2 & & 0 & 1 \\
\hline D. pulchella & 3 & $\begin{array}{l}\text { Scott River, WA; } \\
\text { Baker's Junction, } \\
\text { WA; (white flower, } \\
\text { red center), WA }\end{array}$ & $\mathrm{P}+\mathrm{M}$ & $*$ \\
\hline D. pulchella $\times$ nitidula & 1 & & 0 & 1 \\
\hline D. pulchella $\times$ occidentalis & 1 & & 0 & 1 \\
\hline D. pycnoblasta & 1 & & 0 & 1 \\
\hline D. pygmaea & 1 & & "P" & 3 \\
\hline D. pygmaea & 2 & & 0 & 1 \\
\hline D. pygmaea & 2 & $\begin{array}{l}\text { Windmill Lagoon, } \\
\text { Tasmania; New } \\
\text { Zealand }\end{array}$ & 0 & $*$ \\
\hline D. (paleacea subsp.) roseana & 1 & WA & 0 & $*$ \\
\hline D. (parvula subsp.) sargentii & 1 & WA & M & $*$ \\
\hline D. scorpioides & 2 & & 0 & 1 \\
\hline D. scorpioides & 1 & WA & 0 & $*$ \\
\hline D. sewelliae & 1 & (reddish form) WA & 0 & $*$ \\
\hline D. (barbigera subsp.) silvicola & 1 & WA & 0 & $*$ \\
\hline D. (paleacea subsp.) stelliflora & 1 & WA & 0 & $*$ \\
\hline D. (paleacea subsp.) trichocaulis & 1 & WA & 0 & $*$ \\
\hline D. verrucata & 1 & & 0 & $\begin{array}{c}1 \text { (as " } D \text {. } \\
\text { dichrosepala") }\end{array}$ \\
\hline D. verrucata & 1 & $\begin{array}{l}\text { Fishtrack Road, } \\
\text { WA }\end{array}$ & 0 & * \\
\hline D. walyunga & 1 & Walyunga NP, WA & 0 & $*$ \\
\hline
\end{tabular}

${ }^{a}$ Nomenclature following Lowrie (2014), in parentheses alternative classification following Schlauer (1996).

'P: plumbagin, M: ramentaceone, 0 : no quinone detected

'References

* New/additional data from this study

1 Culham \& Gornall 1994

2 Schlauer 2012

3 Länger et al. 1995 
Fresh leaves of D. roseana, D. scorpioides, and D. pygmaea did not yield quinones, confirming gemmae and/or literature results. No quinones were likewise detected in leaf samples of $D$. minutiflora and D. pedicellaris, of which gemmae contained $\mathbf{M}$. Quinones ( $\mathbf{M}$ and $\mathbf{P}$ ) in trace amounts were detected in leaves of D. pulchella (Mt. Cooke, red flower, Scott River).

\section{Discussion}

Although using gemmae instead of leaves should initially be only a test if less invasive sampling methods can be applied to delicate species, this study produced some noteworthy and chemotaxonomically relevant results. Previously, also seeds were found to contain naphthoquinones (unpublished results) but the amount required to yield reliable signals (usually the entire crop of an individual) cannot be expected to be available from most pygmy sundews, of which several taxa are more or less seedless for various reasons (e.g., self-sterility of the majority of species and usually only single clones available in cultivation, but also hybridity or aneuploidy, Kondo and Lavarack 1984).

The comparison between fresh leaves vs. gemmae confirm our assumption that gemmae are suitable for the investigation of quinone patterns. Especially where only tiny amounts of leaf material were available, gemmae provided more reliable data than leaves ("no detection" is just absence of evidence, not evidence of absence).

The discovery of $\mathbf{M}$ in D. minutiflora (syn. D. parvula: Lowrie 2014: 620), D. pedicellaris, and D. sargentii suggests a close phylogenetic relationship between these taxa as deduced from morphological similarity before (Schlauer 1996; Lowrie 2014: 700 \& 796).

It is rather surprising that no quinone was found in D. pulchella and its hybrids before, as both $\mathbf{M}$ and $\mathbf{P}$ were clearly detected in the gemmae of all three accessions investigated in the present study. This widespread species is fairly isolated within Drosera sect. Bryastrum (Fleischmann, unpublished data) and none of the related taxa yielded any quinone so far. This likewise makes a hybrid origin of $D$. pulchella (that could be assumed from the chemotaxonomic pattern containing both quinones; see Schlauer and Fleischmann 2016) less probable.

The hypothesis that $D$. depauperata is conspecific with $D$. pulchella and just constitutes a depauperate form of it (Lowrie et al. 2017; Fleischmann et al. 2018) is not supported by the very different quinone content of both species, but it remains possible that the former is derived from a hybrid.

Drosera (nitidula subsp.) omissa is the only taxon in the D. nitidula group that contains quinones (predominantly $\mathbf{M}$ with traces of $\mathbf{P}$ ) whatsoever. Only one accession was, however, investigated in the present study, and the group is remarkable for its well documented ability to hybridize even with phylogenetically more remote taxa (Lowrie 2014: 52-56), including the quinone-rich D. pulchella. Interestingly, Culham and Gornall (1994) did not detect quinones in any of the D. pulchella-hybrids investigated in their study. However, as pygmy Drosera were/are frequently misidentified in cultivation, also in botanical gardens and some carnivorous plant nurseries, any previously published data for this group from cultivated material (and without any voucher specimens) has to be taken with some care.

Acknowledgements: Johannes Betz, Thomas Carow, Dieter Kadereit, and Manfred Meisterl are thanked for sharing growing hints and gemmae of pygmy Drosera, some of them since more than two decades. Simon Poppinga and Siegfried Hartmeyer are thanked for reviewing and improving the manuscript. 
References

Culham A., and Gornall, R.J. 1994. The taxonomic significance of naphthoquinones in the Droseraceae. Biochem. System. Ecol. 22: 507-515.

Fleischmann, A., Cross, A.T., Gibson, R., Gonella, P.M., and Dixon, K.W. 2018. Systematics and evolution of Droseraceae. In: Ellison, A.M. and Adamec, L. (eds.): Carnivorous Plants: Physiology, Ecology, and Evolution. Oxford University Press, 45-57.

Goebel, K. 1908. Morphologische und biologische Bemerkungen. 18. Brutknospenbildung bei Drosera pygmaea und einigen Monokotylen. Flora 98: 324-335.

Kondo, K., and Lavarack, P.S. 1984. A cytotaxonomic study of some Australian species of Drosera L. (Droseraceae). Bot. J. Linn. Soc. 88: 317-333.

Länger, R., Pein, I., and Kopp, B. 1995. Glandular hairs in the genus Drosera (Droseraceae). Plant. Syst. Evol. 194: 163-172.

Lowrie, A. 2014. Carnivorous Plants of Australia: Magnum Opus. Redfern Natural History Productions, Poole.

Rivadavia, F., Miranda, V.F.O., Hoogenstrijd, G., Pinheiro, F., Heubl, G., and Fleischmann, A. 2012. Is Drosera meristocaulis a pygmy sundew? Evidence of a long-distance dispersal between Western Australia and northern South America. Ann. Bot. 110: 11-21.

Robinson, A.S., Cross, A.T., Meisterl, M.E., and Fleischmann, A. 2018. A new pygmy sundew, Drosera albonotata (Droseraceae), from the western Wheatbelt and an updated diagnostic key to the orange-flowered pygmy Drosera of Western Australia. Phytotaxa 346: 221-236.

Schlauer, J. 1996. A dichotomous key to the genus Drosera (Droseraceae). Carniv. P1. Newslett. 25: $72-75$.

Schlauer, J. 2012. Literature reviews. Carniv. P1. Newslett. 41: 121.

Schlauer, J., and Fleischmann, A. 2016. Chemical evidence for hybridity in Drosera (Droseraceae). Biochem. Syst. Ecol. 66: 33-36.

Schlauer, J., Hartmeyer, S.R.H., and Hartmeyer, I. 2017. Unexpected discovery of 7-methyljuglone (ramentaceone) in several Australian sundews. Carniv. Pl. Newslett. 46: 20-22.

Schlauer, J., Fleischmann, A., and Carow, T. 2019a. Quinones from "Gondwanan" sundews. Carniv. Pl. Newslett. 48: 13-17.

Schlauer, J., Hartmeyer, S.R.H., and Hartmeyer, I. 2019b. Chemistry and surface micromorphology of the Queensland sundews. Carniv. Pl. Newslett. 48: 111-116.

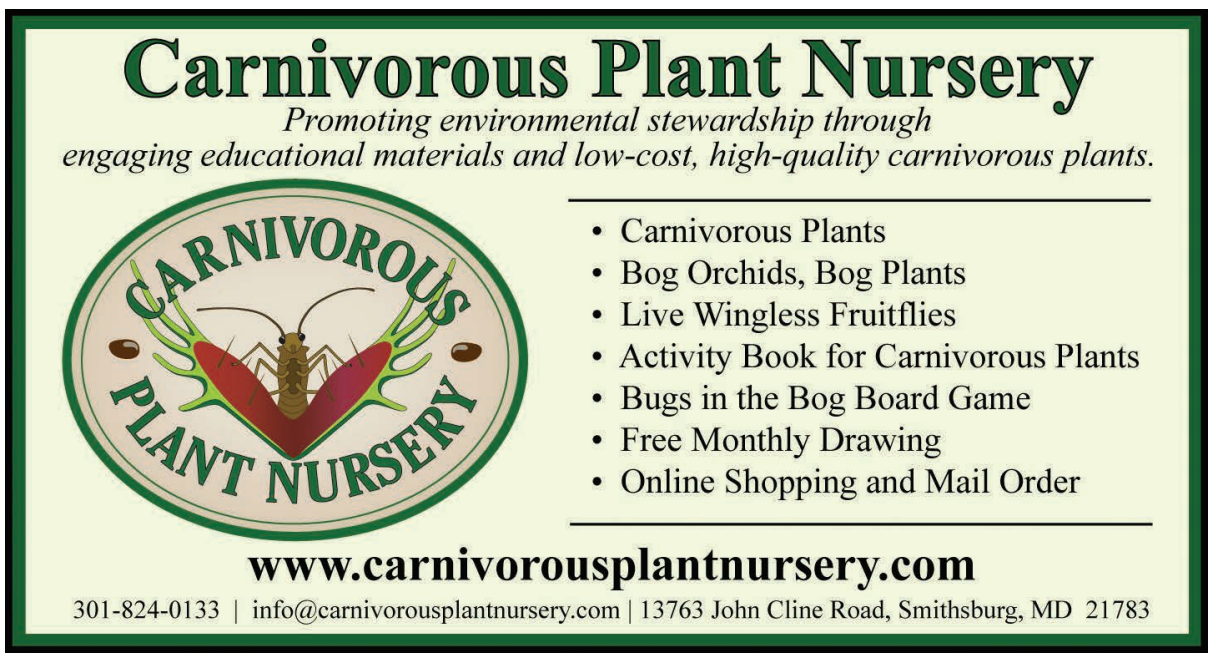

